\title{
Flora da Reserva Ducke, Amazonas, Brasil: Malvaceae
}

\author{
Gerleni Lopes Esteves ${ }^{1}$
}

Schumann, K. 1891. Malvaceae I. In: C. F. P. Martius \& A. G. Eichler (eds.). Fl. bras. 12(3): 253-457, tabs. 51-80.

Gürke, M. 1892. Malvaceae II. In: C. F. P. Martius \& A. G. Eichler (eds.). Fl. bras. 12(3): 457-586, tabs. 81-114.

Ervas a subarbustos. Indumento constituído predominantemente de tricomas estrelados. Folhas simples, alternas, pecioladas, estipuladas; lâminas inteiras a sublobadas, geralmente palmatinérveas. Inflorescências racemosas, multifloras a unifloras. Flores grandes, vistosas, monoclínas, actinomorfas; epicálice geralmente presente, com bractéolas livres entre si; cálice gamossépalo, 5-lobado, prefloração valvar; pétalas 5, livres entre si, imbricadas, adnatas à base do tubo estaminal, com ou sem mancha basal; androceu monadelfo; tubo estaminal com partes livres de estames diversamente distribuídas; anteras monotecas; gineceu com 1-muitos carpelos; ovário (1-)2-muitos lóculos, (1-)2-muitos óvulos por lóculo; estiletes concrescidos até certa altura, separando-se em tantos ramos quanto são os carpelos ou em número dobro ao de carpelos; estigmas capitados. Frutos esquizocárpicos; mericarpos trígonos, múticos, rostrados ou aristados, nervado-reticulados; sementes reniformes ou obovóides; endosperma ausente ou abundante, embrião curvo ou reto, cotilédones em geral dobrados.

Família com mais de 100 gêneros e cerca de 2.500 espécies distribuídas nas regiões tropicais e subtropicais, especialmente na América do Sul, com alguns representantes em regiões temperadas. Caracteriza-se pelo hábito predominantemente herbáceo, indumento na maioria constituído de tricomas estrelados, flores em geral com epicálice, filetes concrescidos em tubo, com anteras monotecas e frutos capsulares ou esquizocárpicos.

A família possui importância econômica, incluindo espécies com potenciais ornamental, medicinal e alimentício, utilizadas como fonte de madeira e de fibras na indústria têxtil, cordoaria e na aniagem.

Na Reserva Ducke está representada por Pavonia cancellata e Sida rhombifolia.

\section{Chave para os táxons de Malvaceae da Reserva Ducke}

1. Ervas prostradas; flores com epicálice; ramos do estilete 10; carpelos 5 .. 1. Pavonia cancellata 1'. Ervas a subarbustos eretos; flores sem epicálice; ramos do estilete 10-12; carpelos 10-12 .......

2. Sida rhombifolia

\section{Pavonia}

Pavonia Cav., Diss. 2 (app.2), 1786; 3:132, t.45-49, 1787.

Ervas com indumento constituído de tricomas estrelados e simples. Folhas com lâminas inteiras. Flores solitárias; epicálice com 4-muitas bractéolas, esverdeadas; cálice cupuliforme, menor que o epicálice; pétalas obovadas, com mancha basal; tubo estaminal menor que as pétalas, parte livre dos estames distribuídas ao longo de todo tubo, anteras reniformes; ramos do estilete em número dobro ao de carpelos. Mericarpos 5, obovóides, face dorsal convexa, faces laterais planas, rostrados; sementes reniformes.

Gênero com cerca de 271 espécies distribuídas no novo e velho mundo. No continente americano ocorrem aproximadamente 223 espécies, desde os Estados Unidos, estendendo-se pela América Central e pelas Antilhas, até o Uruguai.

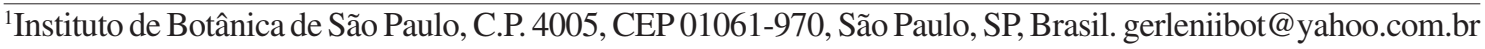


1.1 Pavonia cancellata (L.) Cav. Diss. 3: 135. 1787.

Ervas prostradas; ramos hirsutos, tricomas simples, patentes, esparsos; ramos floridos em geral ascendentes. Folhas com lâminas de 3,75,2 cm compr., 2,6-3,2 cm larg., oval-triangulares, ápice agudo, base sagitada a cordada, margem irregularmente serreada, 5-7 nervuras basais, faces adaxial e abaxial com tricomas simples, adpressos; pecíolos 1,5-2,5 cm compr., com tricomas simples, patentes; estípulas 3-4 mm compr., filiformes. Flores solitárias; pedicelos articulados 1,2-1,7 cm abaixo do epicálice; bractéolas do epicálice 11-14, 1,2-1,3 cm compr., filiformes, longamente ciliadas; cálice 5-9 mm compr., lobos ovais, ciliados; pétalas $2-2,5 \mathrm{~cm}$ compr., amarelas, mancha basal vinácea; tubo estaminal 9-10 mm compr., vináceo. Mericarpos 3-rostrados, face dorsal reticulada, verrucosa, faces laterais lisas, curtamente aladas; rostros com tricomas simples, retrorsos, rostro central ereto, rostros laterais divergentes; sementes pubérulas, vináceas.

Distribuição neotropical, desde o sul dos Estados Unidos (México) até a Região Sudeste do Brasil, com grande representação na América do Sul. Áreas alteradas, solo argiloso.

Floresce e frutifica o ano todo. 10.IX.1994 (fl) Vicentini et al. 674 (INPA).

Espécie com grande variabilidade na morfologia das folhas e nos tipos de indumento e de tricomas. Caracteriza-se pelo hábito prostrado, epicálice com bractéolas filiformes e longamente ciliadas e pelas pétalas amarelas com mancha basal vinácea. Pavonia cancellata assemelha-se à $P$. humifusa A. St.-Hil., espécie com distribuição no Brasil e na Bolívia e distinta pela forma e indumento das folhas e pelo comprimento das pétalas e do tubo estaminal.

\section{Sida}

Sida L. Sp. pl. 683. 1753.

Subarbustos eretos; ramos com tricomas estrelados. Folhas com lâminas inteiras. Inflorescências racemosas; flores sem epicálice; cálice 10-angulado, plicado no botão; pétalas obovadas; tubo estaminal menor que a corola, partes livres de estames distribuídas na porção apical do tubo; ramos do estiletes em número igual ao de carpelos. Mericarpos 5-muitos, obovóides, rostrados, porção basal nervado-reticulada, indeiscente, porção apical lisa, deiscente ou indeiscente; sementes obovóides, hilo apical, côncavo.

Gênero com cerca de 150 espécies com distribuição nas Américas, África, Asia e na Austrália.

2.1 Sida rhombifolia L., Sp. pl. 2:684, 1753. Subarbustos ca. $80 \mathrm{~cm}$ alt.; ramos pubescentes. Folhas com lâminas de 2-3,5 cm compr., 0,8-1,5 cm larg., as apicais menores, subromboidais, ápice agudo, base arredondada, margem crenado-serreada na metade apical, lisa na metade basal, 3-5 nervuras basais, face adaxial glabrescente, face abaxial tomentosa, tricomas estrelados; pecíolos 3-6 mm compr.; estípulas 4-6 mm compr., filiformes. Inflorescências axilares, glomeruliformes, multifloras; cálice 4-5 mm compr., fortemente 10-nervado na base, externamente pubescente, tricomas estrelados, lobos ciliados; pétalas $6-8 \mathrm{~mm}$ compr., amarelas; tubo estaminal 2-4 $\mathrm{mm}$ compr., amarelo; ramos do estilete 10-12. Mericarpos 10-12, reticulados, curtamente 2-rostrados; rostros ca. 0,5 mm compr., paralelos, com tricomas estrelados; sementes $1,5-2 \mathrm{~mm}$ compr., castanhas, pilosas ao redor do hilo

Distribuição pantropical, menos comumente em regiões temperadas. Áreas alteradas, solo argiloso.

Floresce e frutifica o ano todo 30.IV.1996 (fl, fr) Costa \& Assunção 500 (INPA).

A espécie caracteriza-se principalmente pelo cálice 10-nervado na base, com as nervuras proeminentes e pelos mericarpos em número de 10-12, com dois rostros apicais, pequenos e paralelos entre si. 